\title{
Adenovirus-p53 Transduced Dendritic Cell Vaccine
}

National Cancer Institute

\section{Source}

National Cancer Institute. Adenovirus-p53 Transduced Dendritic Cell Vaccine. NCI

Thesaurus. Code C90542.

A cancer vaccine consisting of autologous dendritic cells (DCs) transduced with a recombinant adenovirus encoding p53 peptide, with potential immunomodulating activity. Intradermal vaccination with adenoviral-p53 transduced dendritic cell vaccine may stimulate the host immune system to mount a cytotoxic $T$ lymphocyte $(C T L)$ response against tumor cells expressing mutant p53, resulting in tumor cell lysis. p53, a tumor suppressor gene, is mutated in many tumor cells, resulting in the loss of apoptosis regulation and abnormal cell proliferation. 